\title{
INFLUENCE OF SUBSTRATE TEMPERATURE ON STRUCTURAL, ELECTRICAL AND OPTICAL PROPERTIES OF ZnO:Al THIN FILMS
}

\author{
Sudjatmoko*, Wirjoadi, B. Siswanto \\ Center for Technology of Accelerator and Material Process, BATAN \\ Jl. Babarsari P.O. Box 6101 Ykbb, Yogyakarta 55281, Indonesia \\ Received 17 March 2009; Received in revised form 22 November 2009 ; Accepted 23 November 2009
}

\begin{abstract}
INFLUENCE OF SUBSTRATE TEMPERATURE ON STRUCTURAL, ELECTRICAL AND OPTICAL PROPERTIES OF ZnO:AI THIN FILMS. Transparent and conductive aluminium-doped zinc oxide thin films have been prepared by dc magnetron sputtering technique using targets composed of $\mathrm{ZnO}$ and aluminium. Polycrystalline $\mathrm{ZnO}: \mathrm{Al}$ films were deposited onto a heated glass substrate. Surface morphology and crystalline structure as well as optical and electrical properties of the deposited films were found to depend directly on substrate temperature. From optical and electrical analysis it was observed that optical transmittance and conductivity of the $\mathrm{ZnO}$ : $\mathrm{Al}$ transparent conductive oxide films increased when the deposition temperature was raised from 200 to $400{ }^{\circ} \mathrm{C}$. Films grown on substrates heated at $300{ }^{\circ} \mathrm{C}$ showed a high conductivity value of $0.2 \times 10^{2} \Omega^{-1} \mathrm{~cm}^{-1}$ and a visible transmission of about $80 \%$. The growth of $\mathrm{ZnO}: \mathrm{Al}$ thin films on the surface of glass substrate at temperatures of $300{ }^{\circ} \mathrm{C}$ and aluminium doping levels of 0.9 at.\% were the best to attain $\mathrm{ZnO}: \mathrm{Al}$ films with optical and structural qualities as required for solar cell applications, as a window material in antireflection coatings or optical filters.
\end{abstract}

Keywords : polycrystalline, morphology, conductivity, transmittance.

(C) 2009 Atom Indonesia. All rights reserved.

\section{INTRODUCTION}

With the rapid growing world population and the increasing environmental and social problems of the nowadays common fossil energy production, the need for clean and sustainable energy sources has become evident. Nuclear energy and also solar energy conversion, such as done in photovoltaic systems, can play a major role for electricity production in the urgent needed energy transition. Zinc oxide $(\mathrm{ZnO})$, a semiconducting, photoconducting, piezoelectric and optical waveguide material, shows a wide range of scientific and technological applications. Due to their optical and electrical properties $\mathrm{ZnO}$ thin films have received considerably much attention in recent years. $\mathrm{ZnO}$ has also gained much attention due to the many advantages over other oxide thin films such as tin-doped $\operatorname{In}_{2} \mathrm{O}_{3}$ (ITO) and $\mathrm{SnO}_{2}$ films. These advantages include cheaper and easier to etch than ITO,

* Corresponding author.

E-mail address: sd_moko@yahoo.co.id (Sudjatmoko) 
non-toxicity and much more resistant to hydrogen plasma reduction and can be grown at lower temperatures $[1,2]$.

$\mathrm{ZnO}$ is a n-type semiconductor of wurtzite structure with a direct energy wide-band gap of about $3.37 \mathrm{eV}$ and a large exciton binding energy of about $60 \mathrm{meV}$ at room temperature. It can be used as a transparent electrode in solar cells and flat panel displays as well as for the fabrication of gratings in optoelectronic devices, as a window material in antireflection coatings and in optical filters $[3,4,5,6]$. Furthermore, $\mathrm{ZnO}$ is used as a semiconducting gas sensor, due to its conductivity changes when exposed to oxidizing gases such as ozone. $\mathrm{ZnO}$ nano-structures with excellent optoelectronic properties are used for light emitting diode and laser diodes [7,8], detectors for blue and ultraviolet range of spectrum [9].

In recent years, aluminium-doped zinc oxide ( $\mathrm{ZnO}: \mathrm{Al})$ films prepared by rf or dc magnetron sputtering have emerged as a material for transparent conductive oxide (TCO) used as front contact material and play a crucial role in obtaining high efficiencies with a-Si:H and $\mu \mathrm{c}-\mathrm{Si}: \mathrm{H}$ based solar cells. Besides combining a low series resistance with high transparency, it also has to provide an adequate surface texture for optimized light scattering. Compared with undoped $\mathrm{ZnO}$, Al-doped $\mathrm{ZnO}$ films have lower resistivity and better stability. Several techniques have been used to prepare Al-doped $\mathrm{ZnO}$ films, such as dc magnetron sputtering, chemical vapor deposition, sol-gel and spray pyrolysis [6,10,11]. Among these methods, the dc magnetron sputtering process is used most often, due to high deposition rates and process stability and reliability $[12,13]$. In this work, in order to obtain an excellent transparent conductive oxide (TCO) film for transparent electrode in solar cells, as a window material in antireflection coatings and optical filters with low resistivity and high optical transmittance, aluminium-doped zinc oxide films are deposited on glass substrates by a dc magnetron sputtering method. The influence of substrate temperatures, argon pressures and the effect of impurity doped into the ZnO:Al film on the structural, electrical and optical properties are discussed. X-ray diffraction (XRD), scanning electron microscopy (SEM), the I-V method and spectrophotometer are used to characterize microstructure, electrical and optical properties of the $\mathrm{ZnO}: \mathrm{Al}$ transparent electrode films.

\section{EXPERIMENTAL METHODS}

The glass substrates are ultrasonically cleaned by using acetone, methanol and deionized water, and then dried by blowing nitrogen over them. A $60 \mathrm{~mm}$-diameter disc of sintered $\mathrm{ZnO}$ powder (purity, 99.98\%) and a sintered disc composed of a mixture of $\mathrm{ZnO}$ powder and $<2.0$ wt $\% \mathrm{Al}_{2} \mathrm{O}_{3}$ (purity, 99.98\%) dopant are used as the target. Sputtering is carried out at a pressure of $8 \times 10^{-2}-1.2 \times 10^{-1}$ torr in pure argon gas with a power of $40 \mathrm{~W}$ and the optimum deposition time of $90 \mathrm{~min}$. A magnetic field from the 
external solenoid coil was varied up to about $200 \mathrm{G}$. The glass substrates are placed parallel to the target surface at a distance of $35 \mathrm{~mm}$. Substrate temperatures are varied from $100{ }^{\circ} \mathrm{C}$ to $400{ }^{\circ} \mathrm{C}$ and the surface temperature of the substrate is monitored by a thermocouple and controlled by a heater during the deposition. $\mathrm{ZnO}$ :Al films are deposited onto a heated glass substrates in the temperature region from 100 up to $400{ }^{\circ} \mathrm{C}$, and under optimum argon gas pressure of $9 \times 10^{-2}$ torr. The electrical resistivities are measured at room temperature by using a I-V method; the crystallographic structures are determined by an X-ray diffractometer and the surface morphologies of the films are characterized by a scanning electron microscopy. The optical transmittance is measured in the wavelength range of 300-800 nm with a UV-vis spectrophotometer.

\section{RESULT AND DISCUSSION}

The most important parameter required for the application of $\mathrm{ZnO}: \mathrm{Al}$ films as an excellent transparent conductive oxide (TCO) film for transparent electrode is its low electrical resistivity or high electrical conductivity and high optical transmittance. Hence, emphasis is placed in this study on optimizing of the deposition conditions for substrate temperature and argon pressure, the influences of substrate temperature and argon pressure on the $\mathrm{X}$-ray diffraction patterns, electrical resistivity and optical transmittance of ZnO:Al films.

Variations of $\mathrm{X}$-ray diffraction patterns of $\mathrm{ZnO}: \mathrm{Al}$ films with $\mathrm{Al} / \mathrm{Zn}=0.9$ at.\% deposited at various substrate temperatures are shown in Figure 1. X-ray analysis indicated that the $\mathrm{ZnO}$ :Al films deposited at 200, $250,300{ }^{\circ} \mathrm{C}$ exhibited the c-axis orientation perpendicular to the substrate surface, as can be seen in Figure $1 \mathrm{a}, 1 \mathrm{~b}$ and $1 \mathrm{c}$, respectively. The crystallographic structures are evaluated from the intensities and full width at half-maximum of the (002) diffraction peak and the peak becomes more intense and sharper with increasing substrate temperature. This means that the crystallinity of the $\mathrm{ZnO}: \mathrm{Al}$ films is improved and the grain size of the crystallites becomes larger with increasing substrate temperature up to $300{ }^{\circ} \mathrm{C}$ as shown in the Figure 3. This result indicates that the substrate heating leads to an improvement in the crystallinity of the $\mathrm{ZnO}$ : $\mathrm{Al}$ thin films. 


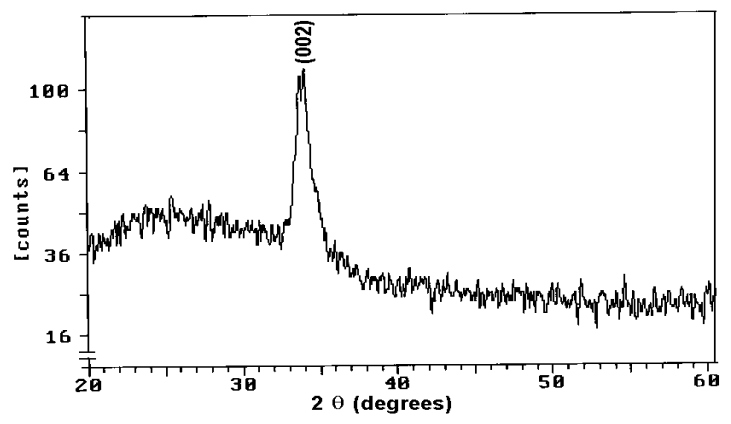

(a)

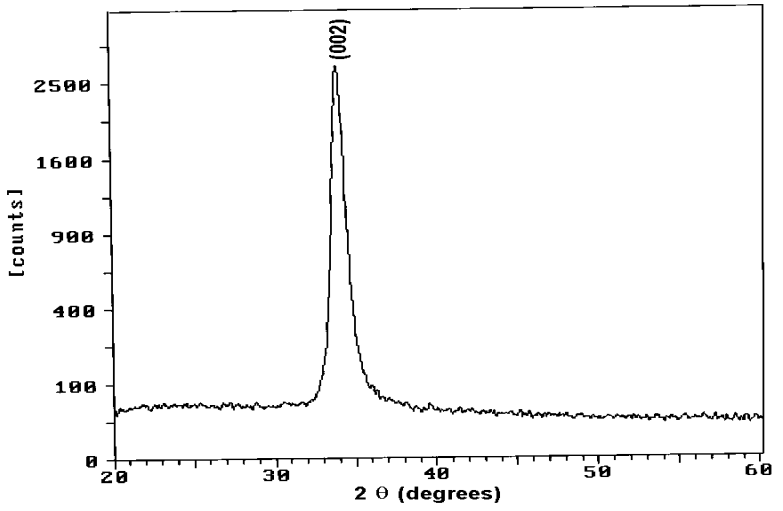

(b)

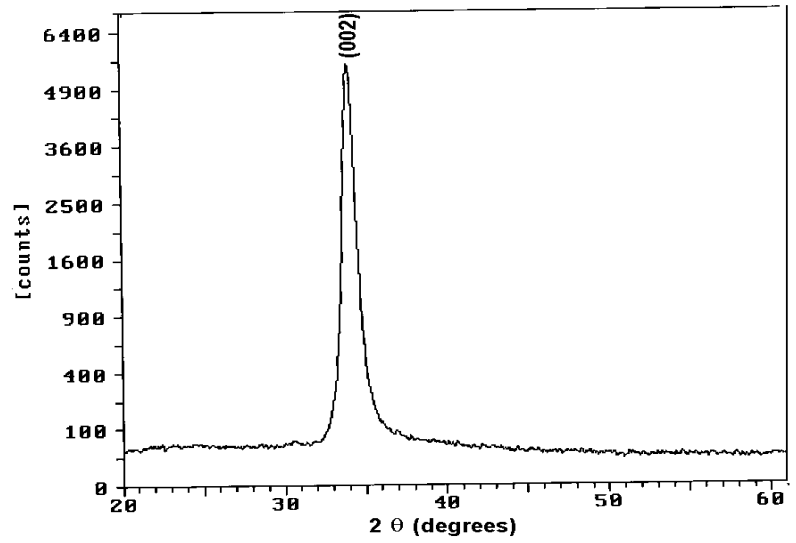

(c)

Figure 1. X-ray diffraction patterns measured on $\mathrm{ZnO}: \mathrm{Al}$ films deposited at substrate temperatures of (a) $200{ }^{\circ} \mathrm{C}$, (b) $250{ }^{\circ} \mathrm{C}$ and (c) $300{ }^{\circ} \mathrm{C}$ respectively. 


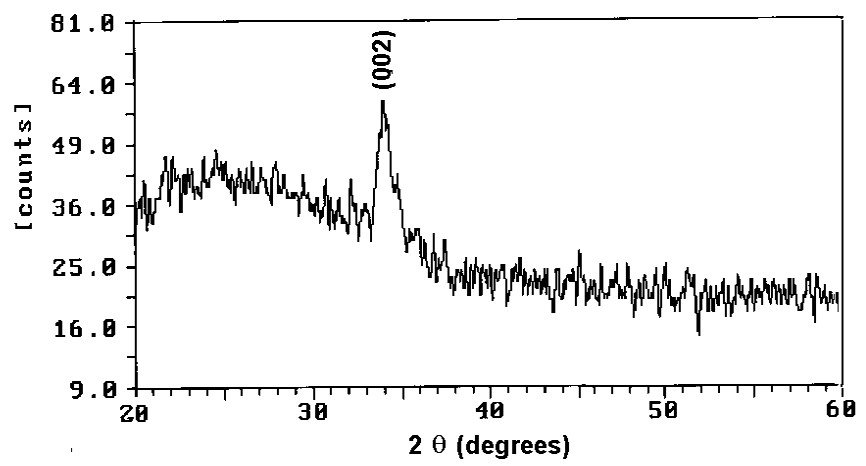

(a)

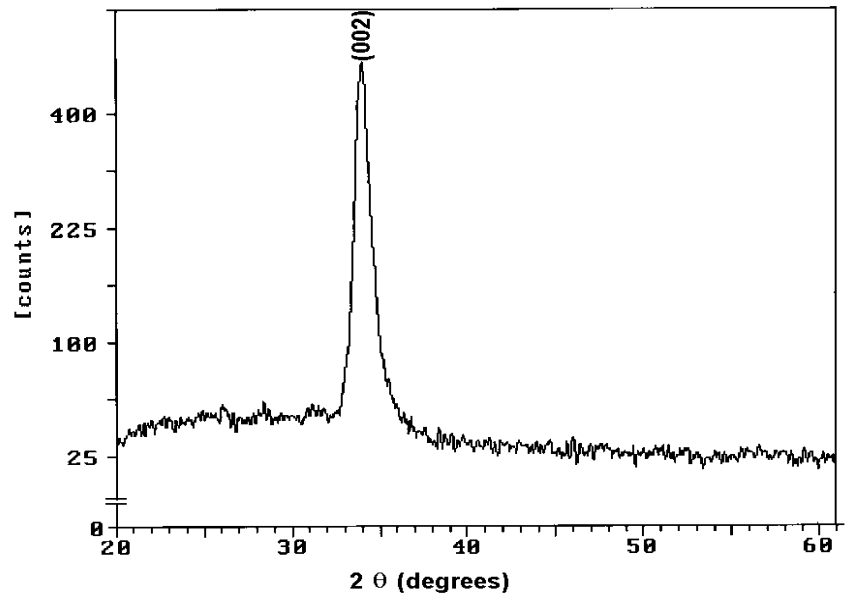

(b)

Figure 2. X-ray diffraction patterns of (a) $\mathrm{ZnO}$ and (b) $\mathrm{ZnO}: \mathrm{Al}$ films, at substrate temperature of $300{ }^{\circ} \mathrm{C}$.

Figure 2 shows the X-ray diffraction spectra of the $\mathrm{ZnO}$ film and the $\mathrm{ZnO}$ :Al film with $\mathrm{Al} / \mathrm{Zn}=0.9$ at.\%, substrate temperature of $300{ }^{\circ} \mathrm{C}$ and argon gas pressure of $1 \times 10^{-1}$ torr. X-ray diffraction analysis indicates that the deposited films are polycrystalline and oriented perpendicular to the substrate surface, i.e. c-axis orientation. The (002) diffraction peak intensity of the $\mathrm{ZnO}: \mathrm{Al}$ film is higher and the half-width is smaller than that of the $\mathrm{ZnO}$ film, an indication that the grain size of the $\mathrm{ZnO}: \mathrm{Al}$ film is larger compared to that of the $\mathrm{ZnO}$ film. The crystallographic orientation correlates with microstructure or morphology of $\mathrm{ZnO}: \mathrm{Al}$ thin films as shown in 
Figure 3. The $\mathrm{ZnO}: \mathrm{Al}$ thin films deposited at lower temperature $\left(200{ }^{\circ} \mathrm{C}\right)$ shown in Figure 3a. has a homogeneous distribution of small grain size which yields a uniform and smooth film. The lateral grain size become bigger at elevated substrate temperature (Figure $3 \mathrm{~b}$ ) of $300{ }^{\circ} \mathrm{C}$ due to the increasing mobility of the constituting atoms at high substrate temperature. In the $\mathrm{ZnO}: \mathrm{Al}$ films deposited on the surface of substrate at a temperatures above $300{ }^{\circ} \mathrm{C}$ is produced a smaller grain size (Figure $3 \mathrm{c}$ ). A mechanism to explain the reason why the higher substrate temperature caused a smaller grain size has not been clarified yet.

The electrical conductivity of $\mathrm{ZnO}: \mathrm{Al}$ films as a function of the substrate temperature is plotted in Figure 4. During the deposition of $\mathrm{ZnO}$ and $\mathrm{ZnO}: \mathrm{Al}$ films, the optimum argon gas pressure is set at $9 \times 10^{-2}$ torr, the dc power is maintained constant, and the $\mathrm{Al} / \mathrm{Zn}$ ratio of the $\mathrm{ZnO}: \mathrm{Al}$ films deposited is about 0.9 at.\%. It is shown that the electrical conductivity of the film increases with elevated substrate temperature and reaches a maximum value at $300{ }^{\circ} \mathrm{C}$, and thereafter decreases slightly. The electrical conductivity of $\mathrm{ZnO}$ :Al films is higher than that of undoped $\mathrm{ZnO}$ films by about five orders of magnitude and the highest conductivity of the $\mathrm{ZnO}: \mathrm{Al}$ film is about $0.2 \times 10^{2} \Omega^{-1} \mathrm{~cm}^{-1}$. The dependence of electrical conductivity upon substrate temperature can be explained by the change in microstructure and the presence of incomplete oxidation of the zinc to form $\mathrm{ZnO}$ films [12]. This result is different from the $\mathrm{ZnO}$ films prepared by using the spray pyrolysis method [14]. 


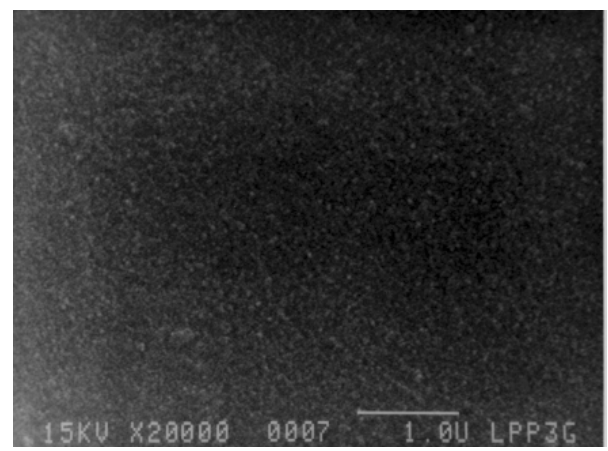

(a)

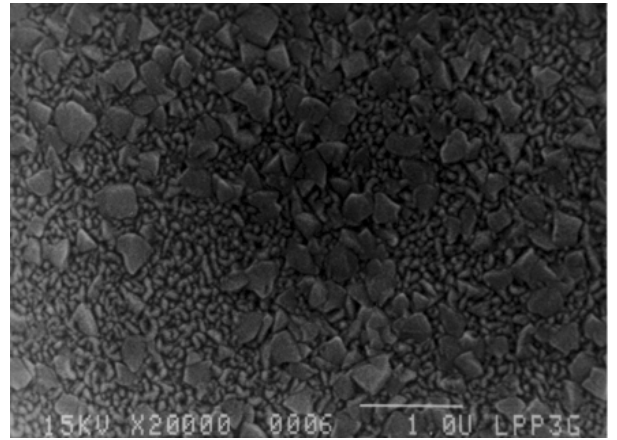

(b)

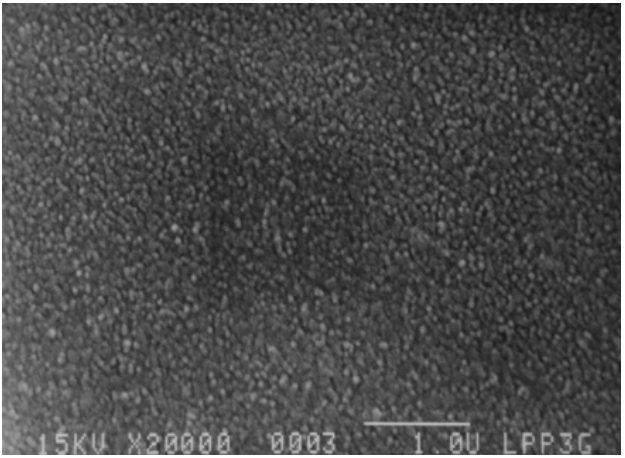

(c)

Figure 3. Scanning electron micrograph taken on the surface of $\mathrm{ZnO}: \mathrm{Al}$ films deposited at (a) $200{ }^{\circ} \mathrm{C}$, (b) $300{ }^{\circ} \mathrm{C}$ and (c) $400{ }^{\circ} \mathrm{C}$.

Figure 5 shows the measured electrical conductivity of $\mathrm{ZnO}$ :Al thin films as a function of the $\mathrm{Al} / \mathrm{Zn}$ ratio. The $\mathrm{ZnO}: \mathrm{Al}$ films were deposited at the substrate temperature of $300{ }^{\circ} \mathrm{C}$, and the argon gas pressure of $9 \times 10^{-2}$ torr, as well as the dc power were maintained constant. It can be seen that the electrical conductivity increases rapidly at a low concentration of $\mathrm{Al}$ and 
reaches a maximum value at $\mathrm{Al} / \mathrm{Zn}=0.9$ at. $\%$, whereas above $\mathrm{Al} / \mathrm{Zn}=0.9$ at. $\%$ the electrical conductivity decreases with increasing $\mathrm{Al}$ concentration. As the Al dopant concentration is increased, more dopant atoms occupy lattice sites of zinc atoms resulting in more charge carriers. Thus the electrical conductivity of $\mathrm{ZnO}: \mathrm{Al}$ film increases with increasing dopant concentration. However, after a certain doping level the dopant atoms in the crystal grain and grain boundaries tend to saturation, resulting in a decreases in the conductivity of the $\mathrm{ZnO}: \mathrm{Al}$ thin films. This result is different with the $\mathrm{ZnO}$ :Al films prepared by the spray pyrolysis method [15] and the sol-gel technique [6].

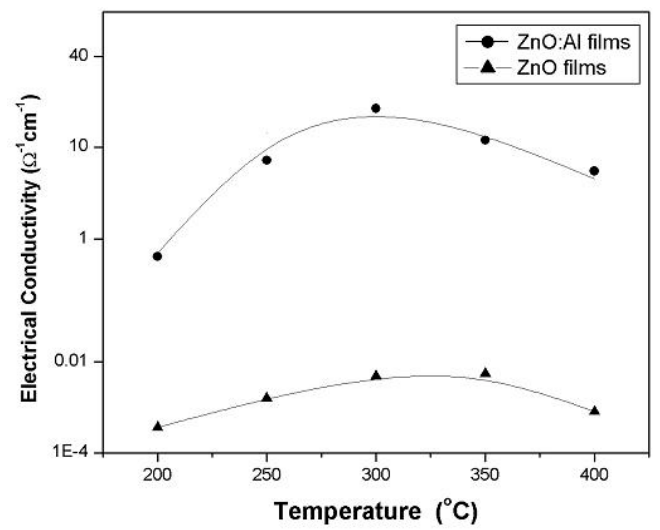

Figure 4. Electrical conductivity values of $\mathrm{ZnO}$ and $\mathrm{ZnO}: \mathrm{Al}$ films as a function of substrate temperature.

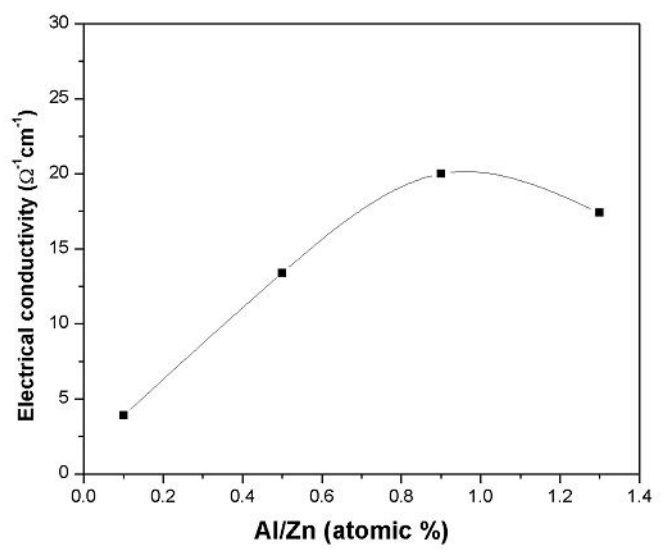

Figure 5. Electrical conductivity of $\mathrm{ZnO}: \mathrm{Al}$ thin films as a function of the $\mathrm{Al} / \mathrm{Zn}$ ratio at substrate temperature of $300{ }^{\circ} \mathrm{C}$, and the sputter gas pressure was maintained constant. 


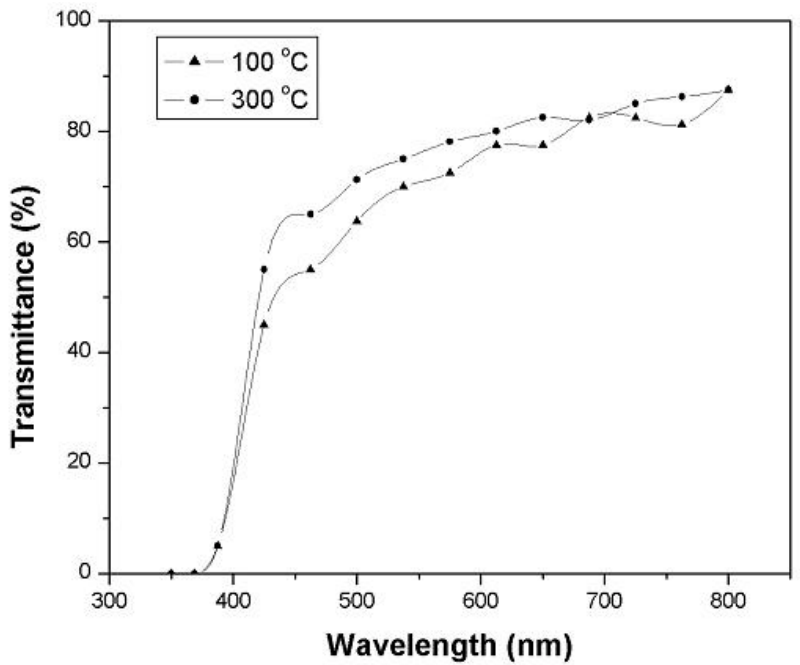

Figure 6. Transmittance spectra of $\mathrm{ZnO}: \mathrm{Al}$ films $(\mathrm{Al} / \mathrm{Zn}=0.9$ at.\%) as a function of the wavelength for film thickness of about $400 \mathrm{~nm}$.

The transmittance characteristics for $\mathrm{ZnO}: \mathrm{Al}$ film is measured in the visible range of $300-800 \mathrm{~nm}$ in wavelength and the results are shown in Figure 6. This film is deposited at the substrate temperature of $100{ }^{\circ} \mathrm{C}$ and $300{ }^{\circ} \mathrm{C}$ each, whereas the sputter gas pressure and the dc power were maintained constant. From the optical transmittance spectrum can be observed that the increase of total transmittance of the film with an increase in growth temperature and a high transmittance in the visible range is obtained in the $\mathrm{ZnO}: \mathrm{Al}$ films. The transmittance spectra of $\mathrm{ZnO}: \mathrm{Al}$ films at wavelengths shorter than about $400 \mathrm{~nm}$ decreased sharply and the average transmittance over the 400 up to $800 \mathrm{~nm}$ is about $80 \%$ in the visible range. The optical transmission of $\mathrm{ZnO}: \mathrm{Al}$ films depend on the deposition temperature. The increase of transmittance may be attributed to the decrease of film thickness, the increase of structural homogenity and the crystallinity of the films. This result is almost the same as the $\mathrm{ZnO}: \mathrm{Al}$ films prepared by using the r.f. magnetron sputtering method [1] or the sol-gel technique [6].

\section{CONCLUSION}

Aluminium-doped zinc oxide transparent conducting films were prepared by the conventional dc magnetron sputtering technique. The influence of substrate temperature and dopant concentration on the structural properties, electrical conductivity and optical properties were investigated experimentally. It was determined that the dc magnetron sputtering technique is a good method to deposit transparent conductive $\mathrm{ZnO}$ :Al thin films. Transparent, high electrical conductivity, c-axis, highly 
oriented $\mathrm{ZnO}: \mathrm{Al}$ thin films were grown on glass substrates by dc magnetron sputtering at different substrate temperatures. The degree of crystallinity, optical transmission, and electrical properties is strongly dependent on the substrate temperature. The glass substrate heating improves the structural and morphological properties of the film and leads to an improvement in carrier mobility by increasing the crystallinity of the film. The $\mathrm{ZnO}$ :Al thin films grown on the surface of substrates at a temperature of $300{ }^{\circ} \mathrm{C}$ showed a high conductivity value of $0.2 \times 10^{2} \Omega^{-1} \mathrm{~cm}^{-1}$. Doping with aluminium significantly increases the conductivity of these films by about five orders of magnitude, and a transmittance of about $80 \%$ in the visible range.

\section{REFERENCES}

1. YIM, K. and LEE, C., Cryst. Res. Technol. 41, 12, 1198-1202 (2006)

2. CHEN, Y., ZHANG, D., and WANG, Q., J. Mater. Sci. Technol, 16, 1, 23-26 (2000).

3. SUCHEA, M., CHRISTOULAKIS, S., MOSCHOVIS, K., KATSARAKIS, N., and KIRIAKIDIS, G., Rev. Adv. Mater. Sci., 10, 335-340 (2005).

4. SUWANBOON, S., Naresuan University Journal, 16, 2, 173-180 (2008).

5. SUCHEA, M., CHRISTOULAKIS, S., MOSCHOVIS, K., KATSARAKIS, N., and KIRIAKIDIS, G. Thin Solid Films, 515, 551-554 (2006).

6. SAGAR, P., KUMAR, M., MEHRA, R.M., Materials Science-Poland, 23, 3, 687-696 (2005).

7. SULIMAN, A.E., and TANG, Y., Journal of Applied Sciences, 7, 2, 314-316 (2007).

8. KIM, I.W., DOH, S.J., KIM, C.C., JE, J.H., TASHIRO, J., and YOSHIMOTO, M., Applied Surface Science, 241, 179-182 (2005).

9. IEVTUSHENKO, A., KARPYNA, V., LASHKAREV, G., LAZORENKO, V., BATURIN, V., KARPENKO, A., LUNIKA, M., and DAN'KO, A., Acta Physica Polonica A, 114, 5, 1131-1137 (2008).

10. CHOU, S.M., TEOH, L.G., LAI, W.H., SU, Y.H., and HON, M.H, Sensors, 6, 1420-1427 (2006).

11. LEE, S.H., Journal of Physics D: Applied Physics, 41, 1-7 (2008).

12. KWAK, D.J., PARK, K.I., KIM, B.S., LEE, S.H., LEE, S.J., and LIM, D.G., Journal of the Korean Physical Society, 45, 1, 206-210 (2004). 
13. SUDJATMOKO, WIRJOADI, BAMBANG SISWANTO, TONO WIBOWO, Prosiding Pertemuan dan Presentasi Ilmiah Teknologi Akselerator dan Aplikasinya, 3, 2, 106-110 (2001).

14. CAGLAR, M., ILICAN, S., and CAGLAR, Y., Trakya Univ., J. Sci., 7, 2, 153-159 (2006).

15. ROZATI, S.M., and AKESTEH, SH., "ZnO:Al thin films obtained by spray pyrolysis: effect of Al concentration", Technical Report, Department of Physics, Guilan University, Iran, 1-3 (2005).

16. LASHKAREV, G.V., LAZORENKO, V.I., KARPYNA, V.A., KHRANOVSKYY, V.D., IEVTUSHENKO, A.I., BLONSKY, I.V., DMYTRUK, I.N., KORENYUK, P.I., BATURIN, V.A., KARPENKO, A.Y., DAN'KO, A.Y., BUDNIKOV, A.T., and GODLEWSKI, M., Physics and Chemistry of Solid State, 9, 2, 375-378 (2008).

17. SULIMAN, A.E., and TANG, Y., Journal of Applied Sciences, 7, 2, 314-316 (2007). 